\title{
PERFORMING LANGUAGE FUNCTIONS IN GERMAN LEGISLATIVE TEXTS
}

\author{
Elena Balashova, Olga Nagoga, Elena Makshantseva \\ Saratov State Legal Academy, Russia \\ E-Mails: ok-fly@mail.ru; balashovaelena@yandex.ru; makela@list.ru
}

\begin{abstract}
The article deals with the functions of legislative texts in German, describes the models of language functions in the context of pragmatic theory, and distinguishes basic, communicative, and specific pragmatic functions of the legal language. The aim of the study is to identify the specific functions of the language and to analyze the peculiarities of their manifestation in the texts of laws in German. The taxonomical and pragmatic methods along with the method of functional analysis were used to create the methodological basis for identifying the specific features of these functions in the texts of laws. As a result of the research, specific language functions were revealed - the functions of nomination, message, communication and influence in German legislative texts. The authors came to the conclusion that the functions of message and influence are more brightly demonstrated in the texts and they are implemented in the text of the law with the help of multilevel linguistic means and their combinations.
\end{abstract}

Key words: legislative text, language function, pragmatics, communicative function, basic and specific language functions.

\section{INTRODUCTION}

In modern linguistics there is the tendency of enhanced studying of language as an instrument of communication and expressing thoughts. The present study highlighted the issues connected with studying language structure, its substance, properties and functions. In the linguistic theory there has been developed a new understanding of the problems of correlations between language and thinking, language and society, language and an individual, language and speech. There are also important issues of examining the substance, system and structure of the language and its functions which are discussed in the present paper.

The study of pragmatic functions of language is crucially important for understanding the specifics of legislative texts' functionality in language and speech. The classical view on general pragmatic language functions was presented in the theories of J.R. Searle and J. Habermas. J.R. Searle determines five pragmatic functions corresponding to five classes of speech acts: assertives (the pragmatic function is to commit the speaker to the truth of the expressed proposition); directives (the pragmatic function is an attempt by the speaker to make the listener perform an act); commissives (the pragmatic function is that the speaker commits himself to perform an act); expressive (the pragmatic function is to express the speaker's psychological state about a state of affairs specified in the

Submitted October $12^{\text {th }}, 2019$, accepted for publication November $5^{\text {th }}, 2019$

C 2019 by University of Niš, Serbia | Creative Commons License: CC BY-NC-ND 
propositional content of the speech act); declaratives (the pragmatic function implies that a successful performance guarantees that the propositional content of the speech act corresponds to the world) (cit. ex. Owen Eriksson. The Pragmatic Language Functionality of Information Systems http://www.vits.org/publikationer/dokument/252.pdf). J. Habermas singles out only 3 major classes: constatives (the pragmatic function is to present states of affairs); expressives (the pragmatic function is to present something from the subjective world of the speaker); regulatives and imperatives united in a single class (the pragmatic function is to regulate the interaction between the actors in the social world (Habermas, 1986).

The inventory of language functions is discussed in many linguistic papers, but in modern pragmatics there is no common understanding of this issue. In Western linguistic tradition the process of communication takes the dominant position. Thus, A. Martine considers communicative, cognitive and emotional functions as the main ones, and the rest are considered as secondary ones (Martine, 1963). K. Bühler structures the basic language functions in a hierarchical manner and in his view, the communicative function acts as a hyper function in that hierarchy. It splits into expressive, appellative and message functions [Bühler,1934]. In Russian linguistic tradition language functions are analyzed either in connection with semiotics or with genre theory. Thus, Yu. S. Stepanov singles out the nominative function covering linguistic units constituing nominal and verbal classes, the predicative function, which is represented by the syntactic relations of words, and the performative function, which includes the units of the communicative act (Stepanov, 1975). V.V. Vinogradov distinguishes the function of message, the function of communication and the function of influence. In his opinion, they are directly connected with functional styles of speech and literary genres and find their expression with the help of various linguistic means (Vinogradov, 1963). Later due to development of pragmatic direction in linguistics language functions were analyzed in a new light, as pragmatics requires the study of language in its relationship with communicants and communicative context.

\section{PRAGMATICS AND LANGUAGE FUNCTIONS}

The term "pragmatics" was first used by Ch. Morris, who considered pragmatics to be "a part of semiotics, which deals with the study of language signs' purpose" (Morris, 1946, 219). Since the late 60's and early 70's of the XX century, linguistic pragmatics has become a separate fieldand has been going on its intensive development up to the present moment. Within the frameworkof traditional linguistics pragmatics is defined as a sphere of linguistics, studying functioning of language units in speech interaction (Formanovskaya, 1998, 34; Stalnaker, 1972, 380; Korpimies, 1983, 21; Mey, 1996, 5; Bulygina, 1981, 333; Arutyunova, Paducheva, 1985, 3; Kiefer, 1985, 333-334).

Pragmatics' ideas go along with the ideas of linguostylistics with a long-standing tradition of studying stylistic means not only in the system of language, but also in specific situations using extralinguistic data. "There is no doubt about the pragmatic nature of stylistic means contributing to enhancing the impact of verbal communication" (Iriskhanova, 2000, 20).

Pragmatics offers a multivariate perspective of studying stylistic facts, which are analyzed in their correlation with a multitude of factors. V.L. Naersingles out such factors of analysis as "the subject of speech and the addressee, their communicative intentions, the purposes, expectations, the communicative situation, the communicative purpose of 
the speech act in the connection with the pragmatic parameters of the statement" (Naer, 1990, 4-9). "In the context of the pragmatic theory the interpretation of the semantic and functional parameters of stylistic means becomes more reasonable and reliable since a multiple system of crossing positions is being created, opening stylistically significant units from different perspectives. There is a shift from a separate, autonomous study of the semantic and pragmatic aspects of stylistic means to their joint, holistic review" (Sarina, 1999).

The language functions, manifested directly in speech acts, were fundamentally clarified in the theory of speech acts of J. L. Austin. Later this theory was developed in the works of J. R. Searle (Searl, 1973). Initially J. L. Austin divided speech acts into "constatives" (statements describing some events) and "performatives" (statements accompanying a description of an event)" (Austin, 1950, 111-128). From those types of speech acts the researcher developed the theory of "locutionary acts". In accordance with this theory, a verbal act can be performed in three ways: by a "locutionary act", when the statement is merely correlated with an event, by an "illocutionary act", when the statement contains a bit more than a mere piece of information about some event and by a "perlocutionary act" when something is said in order to influence on the listener. The difference between illocutionary and perlocutionary acts is that the aim of the former can be put into words, but the aim of the latter is not explicated verbally (Austin, 1975). According to the theory of speech acts, language contains various instruments for expressing different intentions of the speaker. These instruments are included into the communicative competence of both the speaker and the listener; they are relevant to the communicative conditions.

The first linguistic component of communicative situationis language which is a means of communication in itself. It is given to the participants of the communication (addressee and addresser) due to their language experience. In a speech act they select linguistic means to transmit information adequately and to understand the message properly. The second linguistic component of a communicative situation is the message. The message in the language corresponds to the text. The latter can be considered the core of the linguistic communicative situation, the specific containerboth of information intended to be transmitted and the means of transmitting process itself along with the intentions and particular goals that are being pursued by the addresser.

The text cannot exist without thematic content, which is stipulated by the topic of the message or by the denotative correlation of the text in the communicative act. In this case the text exercises the function of message nominationperformed in the form ofthe subject of communication. However, the message also implies the necessity to perform the nominative function of the language. According to G.V. Kolshansky, "any message contains the names of individual objects or phenomena, the logical and grammatical combination of which generates the information itself as an element of communication" (Kolshansky, 1984, 66). Thus, the content of the text assumes the obligatory realization of two language functions in the speech act - message and nomination.

The addresser's communicative intent, psychological by its nature, is realized in the text. From this point of view, the text can be viewed as a means of materializing the ideal content of the addresser's intention. Communicative intention, the purpose of which must be understood by the addressee, is realized through the influence function. This function combines the psychological motives of the addresser and the addressee in the speech act. The influencefunction, performed in the text in the process of speech interaction, transmits the content of the speech act from the verbal-conceptual sphere into the sphere 
of non-speech interaction of communicants. Due to this function in the speech act the text may be studied in terms of pragmatics.

Achieving the communicative goal is connected with understanding by the addressee of both the content and the pragmatics of the text. This understanding is based on the addresser's consideration of addressee's linguistic and communicative competence. Addressing the text to the participants of communication is also a manifestation of the communicative function of the language. Thus, the fulfillment by the text of its role in the speech act is based on the integral communicative function of the language and its pragmatic consequences; therefore, the text reveals both basic, communicative, and special, pragmatic functions of the language. At the same time, in a text that is understood abstractly, the above-mentioned functions are contained potentially, and it is impossible to single out any of them as a leading one. If, however, to concretize the text and turn it from an abstract into an individual speech message, the latter occurs in a concrete speech situation under the influence of specific linguistic factors, the distribution of functional accents in the text is possible. In this case, one or more functions can be leading, and therefore they can give the whole text a certain communicative and pragmatic coloring.

One of the main goals of our paper is analysis of special language functions, which, we believe, can be considered the emanations of an integrated communicative function of language and can be used as the basis for dividing texts into classes with the pragmatic functions of nomination, message, communication and influence. In the texts belonging to one of the classes, the pragmatic intentions of the addresser should dominate. Firstly, it can be an intention for a complex nomination of reality's phenomenon. Secondly, there can be an intention for a detailed message about some fact or event, thirdly - establishing the verbal contact with the addressee, or, in other words, speaking to him or her, and, finally, the necessity to influence on the addressee with some purpose. In order to influence the addressee, the addresser can pursue different goals. These goals determine the kind of reaction of the addressee. Thus, the purpose of the influence and the reaction to it match each other necessarily and they are realized in the linguistic or non-linguistic act or action of the addressee.The purposes of the influence and the reactions can be directed at achieving more or less distant effect. They can be political, aesthetic, moral, ethical or social according to the subject of the message. The reaction to influence can be expressed both in the text of the response and in the non-linguistic actions of the addressee. In relation to the texts of laws, a response can be expressed only in certain actions of the addressee, which potentially may or may not occur in the future.

From the point of view of the addresser, the text is an objective language form chosen from a wide range of linguistic units of the language system to produce the subjective influence on the addressee. And from the point of view of the addressee, the text should have such formal and informative qualities that would prompt him or her to commit or not to commit a certain act of a linguistic or non-linguistic nature.

The material of our research is the text with extralinguistic factors, which are necessary for an adequate understanding of this text (discourse). Business discourse is a specialized cliched version of communication between people who may not know each other, but must communicate in accordance with the norms of society. According to V.V. Nikitina, "business communication has a sociocultural specifics; content and form of business discourse has the socio-semiotic parameters of the corresponding communicative situation" $(2003,75)$.

Any communicative interaction, including business one, occurs in the cultural context in a certain communicative situation. The existence of cognitive models of various communicative 
situations in the minds of individualsis the condition of their successful speech activity. M.A.K. Halliday considers that if the communicative situation meets a set of key parameters, the relevant scenario is actualized in the mind of the individual (1978). V.V. Nikitina distinguishes the following basic parameters: the purpose of communication, the atmosphere of communication (official, neutral, informal), the type of situation (subordinative, nonsubordinative), characteristics of participants of communication (positional, status indicator, situational, role relations), communication channel (oral, written), a set of conventional regulations (rules, norms, values) $(2003,75)$. Each speech act is functionally target-oriented: it has a definite purpose and the methods of actualization. Achievement of purpose is directly dependent upon the sphere of communication and the conditions in which it takes place.

\section{FUNCTIONS OF LEGAL TEXTS}

The legislative text differs from a plain text by a certain communicative purpose. In order to reveal its essence, first of all it is necessary to clarify what is the main purpose of the texts of laws, which communicative purposes and tasks are set by the creators of this type of texts. A legislative text as a genre of formal style has two orientations - to ascertain the fact and to prescribe:

Art. 12. [Berufsfreiheit]

(1) 1 Alle Deutschen haben das Recht, Beruf, Arbeitsplatz und Ausbildungsstätte frei zu wählen. 2 Die Berufsausübung kann durch Gesetz oder auf Grund eines Gesetzes geregelt werden (GG).

$\S 6$. [Prüfung von Amts wegen]

Das Gericht hat seine sachliche Zuständigkeit in jeder Lage des Verfahrens von Amts wegen zu prüfen (StPO).

The text of laws, being intended for maintenance of business relations in the administrative and legal spheres, reflects some state of things in a certain field and urges the addressee to take the necessary actions resulting from that order of things. Relationship between the addresser and the addressee is social, and the pragmatic program is imperative, authoritative and strong-willed by its nature. "The rational program in the text of the law is carried out in detail and is on an equal footing with the pragmatic one, and the emotional program contains rational motivation" (Matveeva, 1990, 62).

Functions of the texts of laws are described in the legal and linguistic literature (c.f.Große, 1976; Tikhomirov, 1992; Turi, 2012; Tiersma, 2003; Berūkštienè, 2016). Lawyers note that laws are one of the most important tools of social regulation. They induce people to active behavior, prescribe, prohibit or allow specific variations of this behavior. Therefore, the law does not act only as a regulator, but also as a direct instrument of controlling action. The language of jurisprudence is aimed at persuasion, it has a moral and legal character and serves as an important means of ideological influence on the addressees and contributes to forming their socio-political consciousness.

According to A.V. Malko, "law as a legal rule is universally binding, formally defined rule of conduct established and enforced by the state and directed at the regulation of public relations" (1999, 129). The rule of law possesses a number of significant features, which include universality, formal certainty, and connection with the state; it also has representative and obligatory nature. The universal character of the rule of law is manifested in the fact that it represents an authoritative prescription of the state regarding the possible and proper behavior 
of people. Its formal certainty is expressed in official written documents, and relationship with the state is established by official bodies and is ensured by the measures of a state's influence - compulsion and stimulation. The obligatory nature of law presupposes the presence in its microsystem structure both of the rights granted to and the duties imposed on the subject of law, and the microsystem structure of law consists of such elements as a hypothesis, disposition and sanction:

$\S 133$. Verwahrungsbruch

(1) Wer Schriftstücke oder andere bewegliche Sachen, die sich in dienstlicher Verwahrung befinden oder ihm oder einem anderen dienstlich in Verwahrung gegeben worden sind, | | zerstört, beschädigt, unbrauchbar macht oder der dienstlichen Verfügung entzieht, | wird mit Freiheitsstrafe bis zu zwei Jahren oder mit Geldstrafe bestraft (StGB).

In the given example of the text of the law all three elements of the legal rule are present. The hypothesis specifies the conditions for the operation of the rule of law, disposition determines the model of individuals' behaviour by establishing rights and obligations, and the sanction provides consequences for the individual who exercises the disposition. Most researchers consider that the core of the rule of law, its main part is disposition, as it contains regulatory provisions affecting the behavior of subjects of law (c.f. Malko, 1999, 130-132; Kashanina, Kashanin, 1996, 63-65).

A clearer denotation of the place, role and purpose of the law as a legal rule in the legal regulatory system is provided by classifications of the norms of law. For our research two most important classifications of legal norms are significant. Those classifications are based on the following criteria:

1) the functional role of the rule of law;

2) the methods of legal regulation.

In the former case, it is necessary to distinguish the original, general and special rules of law. The original rules of law form the basis for the legal regulation of social relations, its goals, objectives and directions. These include, for example, norms that either proclaim principles or contain definitions of specific legal concepts:

$\S 1$. [Beginn der Rechtsfähigkeit]

Die Rechtsfähigkeit des Menschen beginnt mit der Vollendung der Geburt (BGB).

$\S 12$. Verbrechen und Vergehen.

(1) Verbrechen sind rechtswidrige Taten, die im Mindestmass mit Freiheitsstrafe von einem Jahr oder darüber bedroht sind.

(2) Vergehen sind rechtswidrige Taten, die im Mindestmass mit einer geringeren Freiheitsstrafe oder die mit Geldstrafe bedroht sind (StGB).

In most cases, general rules of law are characteristic of any general branch of law, which applies them in the majority of the institutions of this or that area:

$\S 96$. [Rechte als Bestandteile eines Grundstücks]

Rechte, die mit dem Eigentum an einem Grundstücke verbunden sind, gelten als Bestandteile des Grundstücks (BGB).

$\S 62$. Grundsatz der Verhältnismässigkeit.

Eine Massregel der Besserung und Sicherung darf nicht angeordnet werden, wenn sie zur Bedeutung der vom Täter begangenen und zu erwartenden Taten sowie zu dem Grad der von ihm ausgehenden Gefahr ausser Verhältnis steht (StGB).

Special rules of law refer to certain institutions of a particular branch of law and regulate any particular type of social relations taking into account their inherent characteristics. They 
detail and specify the conditions for their realization, as well as ways of legal impact on the behavior of the individual:

$\S 185$. [Verfügung eines Nichtberechtigten]

(1) Eine Verfügung, die ein Nichtberechtigter über einen Gegenstand trifft, ist wirksam, wenn sie mit Einwilligung des Berechtigten erfolgt (BGB).

$\S 142$. Unerlaubtes Entfernen vom Unfallort.

(1) Ein Unfallbeteiligter, der sich nach einem Unfall im Strassenverkehr vom Unfallort entfernt, bevor er

1. zugunsten der anderen Unfallbeteiligten und der Geschädigten die Feststellung seiner Person, seines Fahrzeugs und der Art seiner Beteiligung durch seine Anwesenheit und durch die Angabe, dass er an dem Unfall beteiligt ist, ermöglicht hat oder

2. eine nach den Umständen angemessene Zeit gewartet hat, ohne dass jemand bereit war, die Feststellungen zu treffen,

wird mit Freiheitsstrafe bis zu drei Jahren oder mit Geldstrafe bestraft (StGB).

In the latter case, the legal norms are subdivided into imperative, dispositive, encouraging and recommendatory. At the same time, it is noted that imperative norms contain authoritative prescriptions, dispositive norms suppose freedom to a certain extent, encouraging norms promote socially useful behavior, and recommendatory norms offer the most appropriate ways of behavior for the state and society (Malko, 1999; Marchenko 2004). Imperative and dispositive norms of law are characteristic of German laws texts:

Art. 36. [Beamte der Bundesbehörden]

(1) 1 Bei den obersten Bundesbehörden sind Beamte aus allen Ländern in angemessenem Verhältnis zu verwenden. 2 Die bei den übrigen Bundesbehörden beschäftigten Personen sollen in der Regel aus dem Lande genommen werden, in dem sie tätig sind (GG).

$\S 241$. [Schuldverhältnis und Leistungspflicht]

1 Kraft des Schuldverhältnisses ist der Gläubiger berechtigt, von dem Schuldner eine Leistung zu fordern. 2 Die Leistung kann auch in einem Unterlassen bestehen (BGB).

In the former example we can observe the functioning of imperative rules of law in the legal text, in the latter one - the dispositive legal norms.

Grouping laws as legal rules let us suggest that the texts of laws are not homogeneous in achieving their primary purpose - regulating public legal relations. The structure of the rule of law shows that disposition is its main part regulating and affecting the behavior of the individuals, but the legal norm has no sense without a hypothesis, and it is weak without sanction. Therefore, it is necessary to examine the legal rule or the text of a law considering the interconnection of its structural elements, taking into account the fact that the regulation of legal relations in itself can be different. It is possible to regulate the behavior of subjects of law not only by informing and establishing their rights and obligations through the disposition, but also by means of the consequences - either punitive or incentive measures provided for in the sanction. At the same time, in the former case, we can observe the subject's motivation for socially useful behavior, and in the latter one - the motivation for the omission to do certain acts. The influence of the sanction is more psychological by its nature than the influence coming from the disposition.

The afore cited definitions of the rule of law relating to its essence and designation, the description of its structure and analysis of classifications of the rules of law show that according to their purpose the legal rules and, in particular, the texts of laws perform the function of regulating social relations. 


\section{SPECIAL LANGUAGE FUnCtions OF LEGAL TEXTS}

The four above-mentioned special functions of the language - the functions of nomination, message, communication and influence - have their own peculiarities of manifestation in the German legal texts. To understand the way legal rules perform the function of regulating social relations, it is necessary to analyze the structural elements of the texts of laws and their interrelations from the functional point of view.

\subsection{Nominative Functions}

The nominative function is exercised in the titles of the articles of the law. For naming the articles and structuring the paragraphs nonverbal formatting techniques are also used:

Art. 94 [Bundesverfassungsgericht, Zusammensetzung] (GG)

§ 19 Schuldunfähigkeit des Kindes (StGB).

As the following examples shows, the names of articles or paragraphs of laws are usually printed in boldface type; besides the names of articles of the Basic Law and other laws of Germany are enclosed in brackets, the names of paragraphs in the Criminal and Civil Codes of the Federal Republic of Germany and of some other laws of Germany are given without brackets. To a great extent the nominative function is exercised via legal terms contained in these texts. In the legal language the correct understanding of the whole legal rule often depends on the right usage of the term.

\subsection{The Function of Message}

The function of message in legislative texts can be performed in the form of both the description of actions and situations and information about the possible consequences of certain actions or omissions. In fact the legal norm can regulate the individuals' behavior since it gives some guiding in formation to the addressee. At the same time, the provisions of the law are understood as a kind of social controlling information and are addressed to those who must accept, understand, study and use them. The message in the text of the law is absolutely impersonal. The formal messages of the legal texts are aimed to stimulate the addressee to commit or omit to commit certain actions which are the subject of the article of the law, for example:

$\S 56$. Strafaussetzung

(1) Bei der Verurteilung zu Freiheitsstrafe von nicht mehr als einem Jahr setzt das Gericht die Vollstreckung der Strafe zur Bewährung aus, wenn zu erwarten ist, daß der Verurteilte sich schon die Verurteilung zur Warnung dienen lassen und künftig auch ohne die Einwirkung des Strafvollzugs keine Straftaten mehr begehen wird. Dabei sind namentlich die Persönlichkeit des Verurteilten, sein Vorleben, die Umstände seiner Tat, sein Verhalten nach der Tat, seine Lebensverhältnisse und die Wirkungen zu berücksichtigen, die von der Aussetzung für ihn zu erwarten sind (StGB).

In the text of the paragraph 56 of the Criminal Code of the Federal Republic of Germany, the function of message is realized by informing the addressee of the conditions for the substitution of imprisonment for probation. The notification about these conditions affects the addressee, since it requires his or her strict obedience. In addition, the criteria the court takes into consideration for adjudicating probation, include social background of the defendant, his or her past, circumstances of the crime, his or her behavior after committing the crime, social binds and actions. The appeal to the defendant in the text of the law also influences directly on his or her present and future behavior. 


\subsection{The Function of Communication}

The function of communication is not specific for legislative texts, since the addresser and the addressee are not represented personally. However, as a rule, the texts of laws are known to have a corporate author, who is a legislator. The language of the law as a way of transfer of information from a legislator must consider the characteristics of the target audience, otherwise the information can be misunderstood, lost or distorted.

Taking into account the peculiarities of the individuals accepting the legislative information, presumes at least an approximate knowledge of the scope of persons to whom this or that legislative act is addressed to. The information contained in legal norms must have a concrete addressee, otherwise it will be aimless. When the addressee is not clearly identified, it makes understanding of the legal norm difficult and does not allow to decide the issue about legal responsibility.

Thus, in the text of the law, there is communication between the collective addresserlegislator and a particular addressee, whom a specific legal norm is addressed to. At the same time, the addressee is determined by the legislator in the process of law making, and communication that takes place between the addresser and the addressee is neutral. The influence of the legal rule is extended on a certain group of persons whom this information is addressed to. So when reading the text of the law, the addressee can easily understand whether a legal rule is addressed to him or her or not. E.g., study $\S 9$ of the German Civil Code:

§ 9. [Wohnsitz eines Soldaten]

(1) 1 Ein Soldat hat seinen Wohnsitz am Standort. 2 Als Wohnsitz eines Soldaten, der im Inland keinen Standort hat, gilt der letzte inländische Standort.

(2) Diese Vorschriften finden keine Anwendung auf Soldaten, die nur auf Grund der Wehrpflicht Wehrdienst leisten oder die nicht selbständig einen Wohnsitz begründen können (BGB).

In the given example the addressee of the legal rule raises no doubts - it is obviously a soldier (soldiers), defined in the first and second sentence by the noun "ein Soldat", and in the second sentence by the plural "Soldaten".

\subsection{The Function of Influence}

The function of influence is completely performed in the texts of laws since the texts of this type are intended to exercise certain influence on the consciousness and behavior of the addressee. The information contained in the text of a law influences on the memory and attention of the addressee; declaring the conditions requires their strict fulfilling. Let us study the manifestation of the function of influence on the example of usage of Konjunctiv forms in the texts of laws, which affect the addressee due to declaring the conditions for the eligibility of the action, as well as encouraging the addressee to commit the desired act:

1905. [Sterilisation]

(1) 1 Besteht der ärztliche Eingriff in einer Sterilisation des Betreuten, in die dieser nicht einwilligen kann, so kann der Betreuer nur einwilligen, wenn

1. die Sterilisation dem Willen des Betreuten nicht widerspricht,

2. der Betreute auf Dauer einwilligungsunfähig bleiben wird,

3. anzunehmen ist, dass es ohne die Sterilisation zu einer Schwangerschaft kommen würde, 
4. infolge dieser Schwangerschaft eine Gefahr für das Leben oder die Gefahr einer schwerwiegenden Beeinträchtigung des körperlichen oder seelischen Gesundheitszustandes der Schwangeren zu erwarten wäre, die nicht auf zumutbare Weise abgewendet werden könnte, und

5. die Schwangerschaft nicht durch andere zumutbare Mittel verhindert werden kann. 2 Als schwerwiegende Gefahr für den seelischen Gesundheitszustand der Schwangeren gilt auch die Gefahr eines schweren und nachhaltigen Leides, das ihr drohen würde, weil vormundschaftsgerichtliche Massnahmen, die mit ihrer Trennung vom Kind verbunden wären ( $§ 1666,1666 \mathrm{a})$, gegen sie ergriffen werden müssten (BGB).

In the given example the special form of the subjunctive mood of conditional I (würde kommen, würde drohen) is used with the modal verbs können and müssen to express the special connotations of inducement in the meaning. Along with the meaning of inducement, modal verbs add to the text the connotation of the action's conditional character. Any condition is considered a limitation of the action; this has also a certain effect on the addressee of the text.

\section{CONCLUSIONS}

In the present paper we tried to contribute to development of pragmatics. The results of our research are based on the study of the characteristics of the language functions in legislative texts in the modern German language. The conducted linguistic and pragmatic analysis allows for developing a deeper understanding of the fundamental features of the language system and, to a certain extent, may be applicable to the studies of texts belonging to different genres in other languages. Pragmatics in the XXI century can be described as an actively developing science with the multiple sources of new theoretical problems and applied tasks.

The functions of language reflect its essence, purpose and social nature. The main basic language functions split into special language functions. The latter can be considered the specific actualization of a communicative act's certain elements. The number of special language functions varies in different studies. These functions determine either the basic kinds of speech acts or definite types of speech activity. Thus, the information presented in the legislative text affects the attention and memory of the text's recipient. The text of a law dictates the terms and requires their strict submitting to.

The legislative texts, analyzed in the present paper can be referred to a special type of speech activity. Their pragmatic analysis allows to single out the set of special language functions appropriate for legislative texts: the functions of nomination, message, communication and influence. These functions are exercised in the texts of laws in a specific manner. The most significant function is the function of influence, since it is the function that exercises the communicative goal of a legislative text as a regulator of social relations. Thereby we consider that the function of influence is the basic one for legislative texts because along with the communicative and cognitive functions, it serves the main purposes of the legal text. In the future we think it will be possible to study various types of texts and determine their basic and special functions, the list of which will differ from the typical classification of language functions according to their significance. The research in that direction will allow to change the existing opinion that there are only two basic linguistic functions - communicative and cognitive, and the rest ones are their derivatives. The analysis 
of the language functions of legislative texts makes it possible to systematize the means of realization of this or that special language function.

In perspective the authors intend to develop certain models of the legislative texts which correspond with the special language functions of nomination, message, communication and influence. Modeling the texts of laws can also be refined by attributing the legislative texts to a specific type of legal rules (the models of legislative texts with binding, dispositive, encouraging or recommendatory legal norms).

\section{REFERENCES}

Arutyunova, N. D., Paducheva E. V. 1985. Origins, problems and categories of pragmatics. New In Foreign Linguistics. No. 16, p. 3-42. Linguistic Pragmatics. Moscow: Progress.

Austin, John. 1950. “Truth”, Proceedings of the Aristotelian Society. Supplementary Volume. No. 24, p. 111-128; reprinted in Austin, 1979, p. 117-133. doi:10.1093/019283021X. 003.0005 .

Austin, John. 1975. How to Do Things with Words. 2nd ed., M. Sbisà and J.O. Urmson (eds.). Oxford: Oxford University Press.

Berūkštienè, Donata. 2016. Legal discourse reconsidered: genres of legal texts. Comparative Legilinguistics. Vol. 28. https://pressto.amu.edu.pl/index.php/cl/article/view/7435/7467 DOI : http://dx.doi.org/10.14746/cl.2016.28.5.

Bühler, Karl. 1934. Sprachtheorie. Die Darstellungsfunktion der Sprache. Jena: Fischer.

Bulygina, T.V. 1981. About the scope and content of pragmatics. Proceedings of Academy of Sciences of the USSR. Series of Literature and Language. Vol. 40. Issue 4., p. 333-342. Moscow: Nauka.

Eriksson, Owen. The Pragmatic Language Functionality of Information Systems http://www.vits.org/publikationer/dokument/252.pdf

Formanovskaya, N.I. 1998. Communicative-Pragmatic Aspects of Communication Units.Moscow: IKAR Publishing.

Große, Ernst U. 1976. Text und Kommunikation: EinelinguistischeEinführung in die Funktion der Texte. Stuttgart; Berlin: W. Kohlhammer.

Habermas, Jürgen. 1986. Communicative Rationality and the Theories of Meaning and Action. In: Habermas J. 1998. On the Pragmatics of Communication.(ed). Cooke M., MIT Press, Cambridge, Massachussetts.

Halliday, Michael A. 1978. Language as Social Semiotic: The Social Interpretation of Language and Meaning. London: Edward Arnold.

Iriskhanova, K.M. 2000. Stylistic resources of the language and the paradigm of their research. Stylistic Aspects of Discourse: Collection of Studies.Issue 451, p. 16-26. Moscow: Publishers MGLU.

Kashanina, T.V and Kashanin, A.V. 1996. Fundamentals of Russian Law. Moscow: Publishers group INFRA-M-NORMA.

Kifer, Ferenc. 1985. About the role of pragmatics in the linguistic description. New in Foreign Linguistics. Issue 16, p. 333-347. Linguistic Pragmatics. Moscow: Progress.

Kolshansky, G.V. 1984. Communicative Function and Structure of Language. Moscow: Nauka.

Korpimies, Liisa. 1983. Linguistic Approach to the Analysis and Cohesion with Special Reference to "The Birthday Party” by Harold Pinter. Jyväskylä: University of Jyväskylä. 
Malko, A.V. 1999.Theory of the State and Law in Questions and Answers. 3rd ed. Moscow: Jurist.

Marchenko, M. N. 2004. Theory of State and Law. $2^{\text {nd }}$ ed. Moscow: Prospekt.

Martine, Andre. 1963. Foundations of General linguistics. New in Linguistics [Collection of research papers. Translation]. Vol. 3, p. 347-566. Moscow: Publisher of Foreign Literature.

Mey, Jacob L. 1996. Pragmatics: An Introduction. Oxford: Blackwell.

Morris, Charles. 1946. Signs, Language and Behavior. New York: Prentice Hall, Inc.

Naer, V. L. 1990. Pragmatic essence of stylistic markedness. Problems of Stylistic Markedness (Collection of research papers). Issue 356, p. 4-9. Moscow: Moscow State Linguistic University.

Nikitina, V. V. 2003. English linguocultural specifics of business discourse. Ecolinguistics: theory, problems, methods (Collection of research papers). Saratov: Nauchnaya Kniga. Pp. 74-78.

Sarina, Z. M. 1999. Pragmatic grounds for using repetition in speech forms (PhD degree research paper). Moscow.

Searl, John R. 1973. Linguistik und Sprachphilosophie. Linguistik und Nachbarwissenschaften. In: Renate Bartsch und Theo Vennemann (Hrsg.). Kronberg/Ts. P. 113-125.

Stalnaker, Robert C. 1972. Pragmatics. Semantics of Natural Language.Dordrecht: D. Reidel Publishing Company. P. 380-397.

Stepanov, Yu. S. Methods and principles of modern linguistics. Moscow: Nauka.

Tiersma, Peter M. 2003. The Creation, Structure and Interpretation of the Legal Text, accessed on 18 June, 2018, http:// www.languageandlaw.org/legaltext.htm

Tikhomirov, Yu. A. 1992. The Function of the Law. Moscow: Izvestiya.

Turi, Joseph-G. 2012. Language Law and Language Rights. International Journal of Law,

Language \& Discourse. Volume 2. Issue 4, p. 1-18. Australia, Hong Kong and UK: Academic Scholars Publishing House.

Vinogradov, V.V. 1963. Stylistics, theory of poetic speech, poetics. Moscow: Academy of Sciences of the USSR.

\section{LIST OF SOURCES}

Grundgesetz für die Bundesrepublik Deutschland (GG): Basic Law of FRG. Grundgesetz: Sonderausgabe unter redaktioneller Verantwortung des Verlages C.H. Beck. -35., neubearbeitete Auflage. München, 1998. S. 1-65.

Bürgerliches Gesetzbuch (BGB): Civil Code of FRG. Bürgerliches Gesetzbuch: Sonderausgabe unter redaktioneller Verantwortung des Verlages C.H. Beck. - 40., überarbeitete Auflage. München, 1997. S. 1-454.

Strafgesetzbuch (StGB): Criminal Code of FRG. Strafgesetzbuch: Sonderausgabe unter redaktioneller Verantwortung des Verlages C.H. Beck. - 30. Auflage. München, 1996. S. $1-161$.

Strafprozessordnung (StPO): Criminal Procedure Code of FRG. CD-ROM Schönfelder plus (c), 1997, Verlag C.H. Beck. 